\title{
Management of Consumption Pattern toward Children's Nutritional Status
}

\author{
Anto \\ Universitas Indonesia Timur \\ Makassar, Indonesia
}

\author{
Hermawati Hamalding \\ Universitas Indonesia Timur \\ Makassar, Indonesia
}

\author{
Marhtyni \\ Universitas Indonesia Timur \\ Makassar, Indonesia
}

\begin{abstract}
The research objective was to determine Procedures against Consumption of Nutritional Status of Children. This type of the investigation is observational with cross sectional study. The sampling technique used exhausted sampling with a total sample of 43 children. The result showed that breakfast habits $(p=0.002)$, frequency of eating $(p=0.022)$, parenting nutrition $(p=0.003)$, associated with the nutritional status of children Kindergarten $(<0.05)$. The conclusion shows that there is a link breakfast habits, the frequency of eating, parenting nutrition and nutritional status of children in kindergarten. It is expected that parents should better manage consumption patterns and familiarise breakfast in the morning before the child goes to school because the body needs an intake of nutrients derived from the breakfast to maintain physical endurance and to improve learning ability. Parents play an important role in the nutritional care and schools prepare their children healthy and safe for consumption by their children to foods consumed by children can be monitored.
\end{abstract}

Keywords: nutritional status, consumption patterns, children kindergarten

\section{INTRODUCTION}

Preschoolers are kindergarten children were vulnerable to nutritional problems of public health and are at risk [1]. Good nutrition will play a role in the prevention of various diseases and infections that can support optimal child development. Children ages kindergarten, i.e. 4-6 years including community group called the nutrition of vulnerable groups, i.e. groups most likely to suffer from nutritional disorders. The age range is the golden period of a child's growth, and the development is primarily a function of language, cognitive, and emotional. To support the growth and development, nutritional intake of food is one factor that plays an important role

A Child, early introduction of the social environment, is in the community outside the family. The child in the kindergarten age is experiencing a period of relatively rapid growth. At this age, the child is still in a class of passive consumer, who is unable to pick and choose their food according to their needs. In this age, children are very vulnerable to various health problems such as malnutrition, resulting in disruption of the growth of the body, mental, intelligence and susceptible to disease infection. Besides, malnutrition can also cause obesity and children at the risk of suffering from degenerative diseases such as hypertension and heart disease [2], [3].

Based on data from several health research that the nutritional status of children in Indonesia with indicators of weight/age shows the prevalence of malnutrition of $4.9 \%$, $13.0 \%$ malnutrition and over-nutrition 5.8\% 14. The national prevalence of school-age children who underweight (male) was $13.3 \%$, while the national prevalence of school-age children is underweight (female) was $10.9 \%$. The prevalence of overweight in males $9.5 \%$ and females $6,4 \%$. According to the Province, East Nusa Tenggara has the highest prevalence of underweight both in boys $(23.1 \%)$ and girls (19.1\%). The lowest prevalence of underweight in Bali, namely $8.3 \%$ in boys and $6.9 \%$ girls. Moreover, North Sulawesi has a predominance of school children, who underweight (male) was $9.4 \%$ and the prevalence of underweight children of school age (girls) as much as $7.4 \%$ [4]-[6].

South Sulawesi in 2010 showed malnutrition cases around 4.1\%. The figure is admittedly higher than the figure in the previous year which is only $3.2 \%$. The low nutritional adequacies at the group of school-age children affect the physical growth, concentration, and achievement. Long and severe infections are also closely linked to nutritional problems such as malnutrition. Infection can lead to malnutrition. A child who has an infection requires more nutrition than usual. South Sulawesi Health Office reported that the high rates of malnutrition are less influenced by some factors such as infectious diseases suffered by children, lack of parental knowledge of the food and the low income. Nutritional intake in school-age children was affected by environmental factors because children in this age are starting to know the environment. Therefore, the attention of parents and schools need to be improved to prevent nutritional disorders such as malnutrition or obesity. The participation of the various parties regarding nutritional intake is required to improve the nutritional status of children in Indonesia in general and schoolage children in particular [7].

Based on the monitoring of the nutritional status of children 3-6 years are the number of cases of poor nutrition as much as 4.0\% Malnutrition good nutrition as much as $16.0 \%$ and $72.6 \%$ more nutrition as much as $7.4 \%$. In children of school age, changes in eating patterns were great. If during their meal times, they spent more with his parents, then when entering school age, they eat a lot more when they are with their friends.

\section{RESEARCH METHOD}

This type of the investigation is observational research with a cross-sectional study which was observed in the same period. This research was conducted in kindergarten PGRI Cenranae Wajo. The populations in this study are all children enrolled in the kindergarten. Respondents in this study are the parents/guardians of all students who become caretaker's child nutrition. The sample was taken by exhaust sampling technique sampling as many as 43 children. Data were analysed using SPSS with the chi-square test.

\section{RESULT AND DISCUSSION}

\subsection{Analysis of relationship of breakfast habits with nutritional status of children}

Table 1 shows that of the 19 children who have irregular breakfast habits are children who have normal nutritional status is not as much as $57.9 \%$. While the 24 children who had regular breakfast habit are children who have normal nutritional status is not as much as $12.5 \%$. 


\begin{tabular}{|c|c|c|c|c|c|c|}
\hline \multirow{3}{*}{$\begin{array}{c}\text { breakfast } \\
\text { habits }\end{array}$} & \multicolumn{4}{|c|}{ Nutritional Status } & \multirow{3}{*}{ Total } & \multirow{3}{*}{$\begin{array}{l}x^{2} \\
(p)\end{array}$} \\
\hline & \multicolumn{2}{|c|}{ Abnormal } & \multicolumn{2}{|c|}{ Normal } & & \\
\hline & $\mathbf{N}$ & $\%$ & $\mathbf{n}$ & $\%$ & & \\
\hline Irregular & 11 & 57.9 & 8 & 42.1 & 19 & 9.952 \\
\hline Regular & 3 & 12.5 & 21 & 87.5 & 24 & $(0.002)$ \\
\hline Total & 14 & 32.6 & 29 & 67.4 & 43 & \\
\hline
\end{tabular}

Statistical analysis of the results obtained by $\mathrm{X}^{2}$ count value (9.952)> $\mathrm{X}^{2}$ table $(3.841)$ and the p-value $(0.002)<0.05$, this means breakfast habits associated with nutritional status of children Kindergarten PGRI Cenranae Wajo, South Sulawesi Province.

Breakfast in the morning is very useful as preparation activities, both for children and adults. From breakfast this body gets the intake of nutrients for endurance. Breakfast is very beneficial for adults to maintain physical endurance, while for children schools to improve learning ability. The habit to not eat breakfast for students led to a lack of ability to concentrate learning, for adults cause fatigue, drowsiness and decreased work productivity.

The results showed that of the 19 children of kindergarten declared irregular breakfast habits there that has a normal nutritional status as much as $42.1 \%$; this is assumed irregular children breakfast then a child's daily nutritional especially iron, fiber, and calcium are not met. While of the 24 preschools regular breakfast habit that had normal nutritional status not as much as $12.5 \%$, this is assumed to increase with breakfast habits to meet nutritional needs in the body through the management of the consumption patterns of children.

\subsection{Analysis of relationship of eating frequency with nutritional status of children}

Table 2 shows that of the 20 children who have less food frequency are children who have normal nutritional status is not as much as $47.8 \%$. While the 23 children who had eaten enough frequencies there are children who have normal nutritional status is not as much as $15.0 \%$.

TABLE 2. RELATIONSHIP OF EATING FREQUENCY WITH NUTRITIONAL STATUS OF CHILDREN KINDERGARTEN PGRI CENRANAE, WAJO, SOUTH SUlaWESI

\begin{tabular}{|c|c|c|c|c|c|c|}
\hline \multirow{3}{*}{$\begin{array}{c}\text { Eating } \\
\text { Frequency }\end{array}$} & \multicolumn{4}{|c|}{ Nutritional Status } & \multirow{3}{*}{ Total } & \multirow{3}{*}{$\begin{array}{l}x^{2} \\
(p)\end{array}$} \\
\hline & \multicolumn{2}{|c|}{ Abnormal } & \multicolumn{2}{|c|}{ Normal } & & \\
\hline & $\mathbf{n}$ & $\%$ & $\mathbf{n}$ & $\%$ & & \\
\hline Less & 11 & 47.8 & 12 & 52.2 & 20 & \\
\hline Enough & 3 & 15.0 & 17 & 85.0 & 23 & 5.250 \\
\hline Total & 14 & 32.6 & 29 & 67.4 & 43 & $(0.022)$ \\
\hline
\end{tabular}

Statistical analysis of the results obtained by $\mathrm{X}^{2}$ count value $(5,250)>X^{2}$ table $(3.841)$ and the p-value $(0.022)<0.05$. This means that the frequency of eating associated with nutritional status of children Kindergarten PGRI Cenranae Wajo, South Sulawesi Province.

The level of energy consumption and protein can affect the nutritional status of children. In addition to power consumption and proteins that affect the nutritional status of children is the parents' income and expenditure. Most children aged 3-5 years old eat more than 3 times a day they have a small stomach, so as to feed 5 to $6 \mathrm{x}$ better day than $3 \mathrm{x}$ overday. The frequency of eating seems to be associated with nutrient intake, except when children consume less than $4 x$ or $6 x$ overday. Energy intake of calcium, protein, vitamin $\mathrm{C}$, and iron the children who ate less than $4 \mathrm{x}$ a day, less than the intake of other children her age who eat 4 times a day or more. While the children are eating more than 6x daily energy intake, calcium and vitamin $\mathrm{C}$ is larger than the kids his age who eat less than $6 x$ a day.

The results showed that out of 20 kindergarten children who ate less frequency stated there that has a normal nutritional status $52.2 \%$ assume to increase the frequency of meals to meet the energy intake of calcium, protein, vitamin $\mathrm{C}$, and iron. It is assumed for preschool feeding frequency> 3 times the energy intake of calcium, protein, vitamin $\mathrm{C}$, and iron, there were fewer children compared with the intake of other children his age. It can be developed and managed in a good habit of eating time and in a way that regular feeding of the child will usually eat at the usual time and have been determined. The people of Indonesia usually do the frequency of eating three times: breakfast, lunch, and dinner. However, there are two dining interlude morning and afternoon. Therefore, the environment of children living mainly family's need habituation eating pay attention to health and nutrition.

\subsection{Analysis of relationship of parenting nutrition with nutritional status of children}

Table 3 shows that of the 23 children who have bad nutrition parenting, there are children who have normal nutritional status not as much as $55.0 \%$. While 20 children who have good nutrition are parenting children, who have normal nutritional status not as much as $13.0 \%$.

TABLE 3. RELATIONSHIPS OF PARENTING NUTRITION WITH NUTRITIONAL STATUS OF CHILDREN KINDERGARTEN PGRI CENRANAE WaJo SOUTH Sulawesi PROVINCE

\begin{tabular}{cccccccc}
\hline \multirow{2}{*}{$\begin{array}{c}\text { Parenting } \\
\text { Nutrition }\end{array}$} & \multicolumn{4}{c}{ Nutritional Status } & & \\
\cline { 2 - 5 } & Abnormal & \multicolumn{2}{c}{ Normal } & & \multirow{2}{*}{$\begin{array}{c}\mathbf{x}^{2} \\
(\boldsymbol{p})\end{array}$} \\
\cline { 2 - 5 } Total & $\mathbf{n}$ & $\boldsymbol{\%}$ & $\mathbf{n}$ & & \\
\hline Poor & 11 & 55.0 & 9 & 45.0 & 23 & \\
Good & 3 & 13.0 & 20 & 87.0 & 20 & \\
\hline Total & 14 & 32.6 & 29 & 67.4 & 43 & $(0.003)$ \\
\hline
\end{tabular}

Results of statistical analysis obtained by value of $\mathrm{X}^{2}$ count (8.576)> $\mathrm{X}^{2}$ table $(3,841)$ and the p-value $(0.003)<0.05$. This means nutrition parenting associated with nutritional status of children Kindergarten PGRI Cenranae Wajo South Sulawesi province.

Parenting a child is an indirect cause which could affect the nutritional status of children. Inadequate quality of child care is the important base of $4 x$ meal a day or more. Of the 23 kindergarten children who eat enough frequency that has a normal nutritional status not as much as $15.0 \%$. It is the lack of interest of parents regarding food. Parenting covers six key aspects which include care and protection for children, breastfeeding practices and the provision of breastfeeding, psychosocial care, food preparation, personal hygiene and environmental sanitation and hygiene practices at home and search patterns of health services. The interaction of parents with children influence the choice of food and the development of children's eating habits. If the parents are not too responsive in managing their children favor to a particular food, this habit will quickly pass. However, when parents are hard to accept this behavior and attention that many of these issues to induce or encourage children to eat other foods. Assistance during meals, 
parenting will influence on children's food quality.

The results showed that of the 23 preschool parenting are not good nutrition that has a normal nutritional status as much as $45.0 \%$. It is assumed for the child nutrition parenting is not good then the effect on food choices and the development of children's eating patterns. Of the 20 preschool upbringing, good nutrition has a normal nutritional status not as much as $13.0 \%$. It is assumed that the increase good parenting to children will improve the treatment of the development of children's eating patterns.

\section{CONCLUSION}

Based on the research that has been carried out, it can be concluded that the breakfast habits, the frequency of eating, nutrition parenting patterns associated with the nutritional status of preschool children.

\section{REFERENCES}

[1] C. Hu et al., "Evaluation of a kindergarten-based nutrition education intervention for pre-school children in China," Public Health Nutr., vol. 13, no. 2, pp. 253-260, 2010.

[2] A. C. da Silva, M. de Sousa Tavares, and M. G. M. G. Penido, "Prevalence of risk factors for cardiovascular and kidney disease in Brazilian healthy preschool children," World J. Nephrol., vol. 5, no. 6, p. 507, 2016.

[3] R. Moench-Pfanner and M. W. Bloem, "ASEAN: Insights and considerations toward nutrition programs." SAGE Publications Sage CA: Los Angeles, CA, 2013.

[4] K. E. Agho, K. J. Inder, S. J. Bowe, J. Jacobs, and M. J. Dibley, "Prevalence and risk factors for stunting and severe stunting among under-fives in North Maluku province of Indonesia," BMC Pediatr., vol. 9, no. 1, p. 64, 2009.

[5] C. Nazri et al., "Factors influencing mother's participation in Posyandu for improving nutritional status of children under-five in Aceh Utara district, Aceh province, Indonesia," BMC Public Health, vol. 16, no. 1, p. 69, 2016.

[6] S. Bardosono, S. Sastroamidjojo, and W. Lukito, "Determinants of child malnutrition during the 1999 economic crisis in selected poor areas of Indonesia," Asia Pac. J. Clin. Nutr., vol. 16, no. 3, pp. 512-526, 2007.

[7] F. Vio, J. Salinas, E. Montenegro, C. G. González, and L. Lera, "Impact of a nutrition education intervention in teachers, preschool and basic school-age children in Valparaiso region in Chile," Nutr. Hosp., vol. 29, no. 6, pp. 1298-1304, 2013. 